\title{
Pengolahan Citra untuk Membedakan Ikan Segar dan Tidak Segar Menggunakan Convolutional Neural Network
}

\author{
Arif Agustyawan \\ Fakultas Informatika, Program Studi S1 Informatika, Institut Teknologi Telkom Purwokerto \\ 17102123@ittelkom-pwt.ac.id
}

Info Artikel

Kata Kunci :

CNN, ikan segar, pengolahan citra, deep learning, jaringan saraf

\section{Keywords :}

CNN, fresh fish, image processing, deep learning, neural network

\section{Tanggal Artikel}

Dikirim : 21 Juli 2020

Direvisi : 27 November 2020

Diterima : 30 November 2020

\section{Abstrak}

Proses penyortiran ikan yang dilakukan oleh nelayan atau penjual, untuk menyeleksi ikan berdasar kualitasnya masih menggunakan metode manual dan terkadang meleset karena faktor keterbatasan indra penglihatan ketika lelah. Selama ini pemeriksaan hanya dillihat secara fisik. Akibatnya, saat akan dikonsumsi ikan tersebut kerap kali sudah rusak. Penelitian ini mencoba menerapkan algoritma Convolutional Neural Network (CNN) untuk membedakan ikan segar dan tidak segar. Convolutional Neural Network merupakan salah satu metode deep learningyang mampu melakukan proses pembelajaran mandiri untuk pengenalan objek, ekstraksi objek, dan klasifikasi objek. Pada penelitian ini, diterapkan algoritma Convolutional Neural Network untuk membedakan ikan segar dan tidak segar. Proses learning jaringan menghasilkan akurasi $100 \%$ terhadap data training dan data validation. Pengujian terhadap data testing juga menghasilkan akurasi 100\%. Hasil penelitian ini menunjukan bahwa penggunaan metode Convolutional Neural Network mampu mengidentifikasi dan mengklasifikasikan ikan segar dan tidak segar dengan sangat baik.
Abstract
The fish sorting process carried out by fishermen or sellers, to select fish based on quality is still using manual methods and sometimes misses due to the limited sense of sight when tired. So far the examination has only been seen physically. As a result, the fish will often be damaged when consumed. This study tries to apply the Convolutional Neural Network (CNN) algorithm to distinguish between fresh and non-fresh fish. Convolutional Neural Network is a method of deep learning that is capable of conducting independent learning processes for object recognition, object extraction, and object classification. In this study, the Convolutional Neural Network algorithm is applied to distinguish between fresh and non-fresh fish. Network learning process produces $100 \%$ accuracy of training data and data validation. Testing of testing data also results in 100\% accuracy. The results of this study indicate that the use of the Convolutional Neural Network method can identify and classify fresh and non-fresh fish very well. 


\section{PENDAHULUAN}

Indonesia yang merupakan negara kepulauan yang diapit oleh dua samudra yaitu Samudra Hindia dan Samudra Pasifik memungkinkan Indonesia memiliki keberagaman ikan. Selain itu keberagaman ini membuat kegiatan ekspor ikan Indonesia sangat tinggi [1]. Dalam bidang perikanan dilihat dari proses penyortiran ikan yang dilakukan oleh nelayan atau penjual, untuk menyeleksi ikan berdasar kualitasnya masih menggunakan metode manual dan terkadang meleset karena faktor keterbatasan indra penglihatan ketika lelah. Selama ini pemeriksaan hanya dillihat secara fisik. Akibatnya, saat akan dikonsumsi ikan tersebut kerap kali sudah rusak [2]. Ada banyak penelitian yang menangani masalah pemeriksaan kualitas kesegaran pada ikan. Salah satu metode penelitian sebelumnya yaitu dengan memanfaatkan pengolahan citra digital. Pengolahan citra dilakukan untuk proses pengambilan informasi objek atau pengenalan objek yang ada pada citra [3]. Metode pengolah citra digital juga diterapkan dalam metode klasifikasi deep learning. Deep learning merupakan bidang ilmuyang baru dalam bidang pembelajaran mesin (machine learning). Deep learning memiliki ability atau kemampuan yang sangat baik dalam computer vision [4]. Saat ini perkembangan teknologi di bidang computer vision dengan penerapan convolutional neural networkmenunjukkan kinerja dengan tingkat keakuratan tinggi, contohnya yaitu pada deteksi objek [5]. Dalam Deep Learning, CNN merupakan deep neural network, yang paling umum diterapkan untuk menganalisis sebuah citra [6]. Saat ini metode Convolutional Neural Network (CNN) memiliki hasil paling akurat dalam pengenalan citra. Hal tersebut karena CNN meniru sistem pengenalan citra pada visual cortexmanusia, sehingga memiliki kemampuan untuk mengolah suatu informasi yang terdapat pada suatu citra [7]. Beberapa penelitian mengenai pengolahan citra dengan menggunakan metode CNN dengan hasil akurasi yang bagus yaitu penelitian yang dilakukan oleh Erlyna Nour Arrofigoh dkk dalam [8] dengan hasil penelitian dengan akurasi sebesar 82\% yang digunakan untuk mengklasifikasi tanaman. Kemudian penelitian Afandi Nur Aziz Thohari dkk dalam [9] dengan akurasi sebesar 96,7\% yang digunakan untuk mengklasifikasikan pembalap MotoGP. Untuk identifikasi kesegaran ikan sendiri juga telah dilakukan banyak penelitin dengan metode lain, seperti yang dilakukan oleh Wella dkk dalam [10] yang membandingkan algoritma KNN ( $K$ Nearest Neighbor), C4.5 dan Naive Bayes untuk mengklasifikasikan kesegaran ikan. Kemudian penelitian yang dilakukan oleh Saleh Dwiyatno dkk dalam [2] juga menggunakan KNN untuk mendeteksi kesegaran ikan. Dari uraian latar belakang masalah dan kajian literatur singkat di atas maka penulis akan menggunakan CNN yang bertujuan untuk membedakan ikan segar dan tidak segar.

\section{METODE PENELITIAN}

\subsection{Tahapan Penelitian}

Secara garis besar penelitian ini dibagi menjadi 4 tahapan yaitu: 1) Akuisisi data, 2) Preprocessing, 3) Proses ekstraksi fitur, 4) Identifikasi dan klasifikasi.

Desain jalannya penelitian ditunjukkan pada Gambar 1.

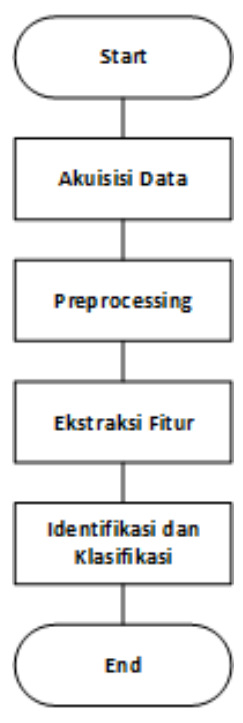

Gambar 1. Tahapan Penelitian 


\subsubsection{Akuisisi Data}

Proses akuisisi data dilakukan dengan menggunakan kamera handphone Samsung A6+ dengan resolusi 4:3 (16 MP) 4608×3456 piksel yang ditempatkan dalam posisi statis sejauh $10 \mathrm{~cm}$ dari objek. Pada penelitian ini objek yang digunakan adalah ikan mujair.

\subsubsection{Preprocessing}

Preprocessing dilakukan dengan cara cropping citra ikan mujair dilakukan untuk memotong ukuran citra yang akan diproses juga untuk lebih memfokuskan pada fitur objek yaitu pupil mata. Hal ini digunakan untuk mempercepat proses komputasi [11].

\subsubsection{Proses Ekstraksi Fitur}

Proses yang terjadi pada bagian ini adalah melakukan encoding dari sebuah image menjadi features yang berupa angka-angka yang merepresentasikan image tersebut (Feature Extraction). Feature extraction layerterdiri dari dua bagian yaitu Convolutional Layer dan Pooling Layer. Namun kadang ada beberapa riset/paper yang tidak menggunakan pooling [12].

\subsubsection{Identifikasi Dan Klasifikasi}

Pada tahap ini, dilakukan training dan validation menggunakan Convolutional Neural Network. Training dilakukan menggunakan data training yang yang telah diekstraksi untuk membedakan antara ikan segar dan ikan tidak segar. Sedangkan untuk validation dilakukan menggunakan data validation. Setelah itu dilakukan evaluasi untuk mengetahui nilai akurasi dan loss value dengan membandingkan hasil keluaran target. Tahap berikutnya adalah testing, pada tahap ini data yang dihasilkan dari training akan digunakan untuk memetakan data uji sehingga diperoleh data keluaran, kemudian diklasifikasikan.

\subsection{Ikan Segar Dan Tidak Segar}

Berdasarkan SNI 01-2729.1-2006, ciri-ciri ikan segar adalah sebagai berikut [1]:

1. Pupil pada mata hitam menonjol dengan kornea yang bening.

2. Insang berwarna merah tua dan tidak mengeluarkan lendir.

3. Daging elastis (kenyal) dan padat jika ditekan.

4. Lendir dipermukaan kulit bening dan tidak berwarna.

Sedangkan ciri-ciri ikan yang tidak segar adalah sebagai berikut:

1. Pupil mata tampak sangat keruh.

2. Warna insang terlihat berubah kecokelatan.

3. Memiliki tekstur daging yang lembek.

4. Mulai tercium bau yang tidak enak.

\subsection{Convolutional Neural Network}

Convolutional Neural Network (CNN) merupalan pengembangan dari Multi Layer Perceptron (MLP) untuk mengolah data dua dimensi (2D) [13]. Model CNN memodifikasi arsitektur Jaringan Saraf Tiruan (JST) sedemikian sehingga dapat langsung memproses citra digital dengan konsep-konsep dasar pengolahan citra digital. Modifikasi tersebut dilakukan utamanya melalui penambahan convolution layer yang memproses citra digital dengan operasi konvolusi. Matriks filter (biasa disebut juga kernel) yang digunakan pada operasi konvolusi terus diperbaharui sepanjang proses pelatihan. Hal inilah yang membuat CNN dapat secara otomatis memilih fitur yang paling sesuai untuk citra digital yang dikelolanya. Dengan menggunakan JST biasa, peneliti harus sangat cermat dalam memilih fitur citra digital yang akan dijadikan input. Dengan CNN proses tersebut adalah bagian dari pelatihan. Pada lapisan akhir CNN yang disebut fully-connected layer, proses yang dijalankan tidak jauh berbeda dengan JST pada umumnya [14].

\subsubsection{Convolutional Layer}

Convolutional Layeradalah lapisan pada CNN yang bertugas untuk melakukan proses konvolusi dari citra digital input dengan menggunakan filter telah ditentukan untuk mendapatkan feature map. Filter yang digunakan pada 
proses Convolutional Layer adalah berukuran $3 \times 3$. Proses dari konvolusi juga dapat ditentukan berdasarkan dari pergeseran filter yang dimasukan atau yang biasa disebut dengan Stride yang bernilai 1 [15].

Proses konvolusi dapat dilihat pada Gambar 2.

\begin{tabular}{|l|l|l|l|l|l|}
\hline $\mathbf{1}$ & $\mathbf{2}$ & $\mathbf{2}$ & $\mathbf{4}$ & $\mathbf{2}$ & $\mathbf{1}$ \\
\hline $\mathbf{3}$ & $\mathbf{3}$ & $\mathbf{3}$ & $\mathbf{7}$ & $\mathbf{3}$ & $\mathbf{2}$ \\
\hline $\mathbf{0}$ & $\mathbf{1}$ & $\mathbf{1}$ & $\mathbf{2}$ & $\mathbf{0}$ & $\mathbf{4}$ \\
\hline $\mathbf{1}_{\times 0}$ & $\mathbf{2}_{\times 0}$ & $\mathbf{1}_{\times 0}$ & $\mathbf{1}$ & $\mathbf{8}$ & $\mathbf{6}$ \\
\hline $\mathbf{2}_{\times 1}$ & $\mathbf{4}_{\times 1}$ & $\mathbf{1}_{\times 1}$ & $\mathbf{2}$ & $\mathbf{3}$ & $\mathbf{2}$ \\
\hline $\mathbf{2}_{\times 0}$ & $\mathbf{1}_{\times 0}$ & $\mathbf{2}_{\times 0}$ & $\mathbf{3}$ & $\mathbf{1}$ & $\mathbf{2}$ \\
\hline
\end{tabular}

Konvolusi menggunakan Kernel Filer $3 \times 3$ dan Stride 1

\begin{tabular}{|c|c|c|c|}
\hline 3 & 7 & 7 & -2 \\
\hline 2 & 2 & 1 & 2 \\
\hline 2 & 0 & 8 & 13 \\
\hline 3 & & & \\
\hline
\end{tabular}

\section{Gambar 2. Proses Konvolusi [15]}

\subsubsection{ReLu Layer}

Retrified Linear Unit ( $R e L u$ ) layer adalah adalah lapisan yang menerapkan fungsi aktivasi ReLu. Fungsi aktivasi ReLu ini mengambil sebuah nilai input dan membatasi nilainya sampai nol yaitu mengubah nilai negatif menjadi nol berguna untuk menghilangkan nilai negatif pada hasil layer sebelumnya [15].

Adapun persamaan yang digunakan pada ReLu menggunakan persamaan berikut:

$$
y=\max (x, 0)
$$

Proses ReLu Layer dapat dilihat pada Gambar 3.

\begin{tabular}{|c|c|c|c|}
\hline 3 & 7 & 7 & -2 \\
\hline 2 & 2 & 1 & 2 \\
\hline 2 & 0 & 8 & 13 \\
\hline 3 & -1 & 4 & 3 \\
\hline
\end{tabular}

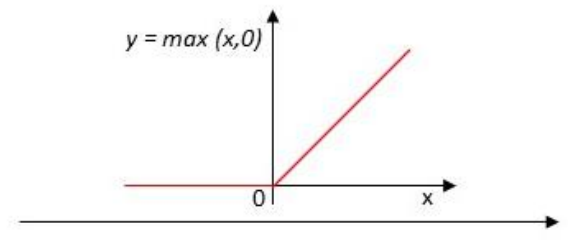

\begin{tabular}{|c|c|c|c|}
\hline 3 & 7 & 7 & 0 \\
\hline 2 & 1 & 1 & 2 \\
\hline 2 & 0 & 8 & 13 \\
\hline 3 & 0 & 4 & 3 \\
\hline
\end{tabular}

\section{Gambar 3. Proses ReLu Layer [15]}

\subsubsection{Pooling Layer}

Pooling layer adalah sebuah filter dengan ukuran dan stride tertentu yang akan bergeser pada seluruh area feature map. Proses pooling yang umum digunakan adalah max pooling yaitu mencari nilai maksimum dalam suatu area tertentu. Hal ini bertujuan untuk mengurangi ukuran feature map pada layer sebelumnya. Ukuran filter yang digunakan adalah $2 \times 2$ dengan nilai stride 1 [15].

Proses pooling layer dapat dilihat pada Gambar 4.

\begin{tabular}{|c|c|c|c|}
\hline 3 & 7 & 7 & 0 \\
\hline 2 & 1 & 1 & 2 \\
\hline 2 & 0 & 8 & 13 \\
\hline 3 & 0 & 4 & 3 \\
\hline
\end{tabular}

Max Pooling menggunakan

Kernel Filter $2 \times 2$ dan Stride 1

\begin{tabular}{|c|c|c|}
\hline 7 & 7 & 7 \\
\hline 3 & 8 & 13 \\
\hline
\end{tabular}

\section{Gambar 4. Proses Pooling Layer [15]}

\subsubsection{Flatten Layer}

Pada lapisan ini dibentuk suatu nilai vektor yang terbentuk dari nilai matrix dari hasil proses max pooling feature map. Hasil flatten layer ini kemudian menjadi nilai input yang akan dimasukan pada Fully connected Layer untuk mendapatkan hasil klasifikasi [15]. 
Ilustrasi proses pada flatten layer dapat dilihat pada Gambar 5.

\begin{tabular}{|c|c|c|}
\hline 7 & 7 & 7 \\
\hline 3 & 8 & 13 \\
\hline
\end{tabular}

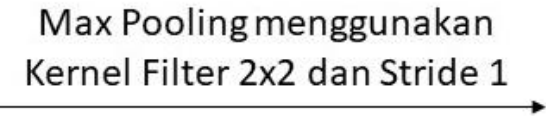

Max Pooling menggunakan
Kernel Filter $2 \times 2$ dan Stride 1

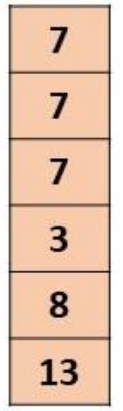

\section{Gambar 5. Proses Flatten Layer[15]}

\subsubsection{Fully Connected Layer}

Pada lapisan ini memiliki bentuk yang sama persis dengan Multi Layer Percepton dimana setiap inputan terhubung pada neuron di hidden layer untuk didapatkan hasil output berdasarkan nilai bobot dan bias dengan fungsi aktivasi ReLu. Fully connected Layer mendapat nilai input dari hasil flatten layer pada proses sebelumnya [15].

Ilustrasi Fully connected Layer dapat dilihat pada Gambar 6.

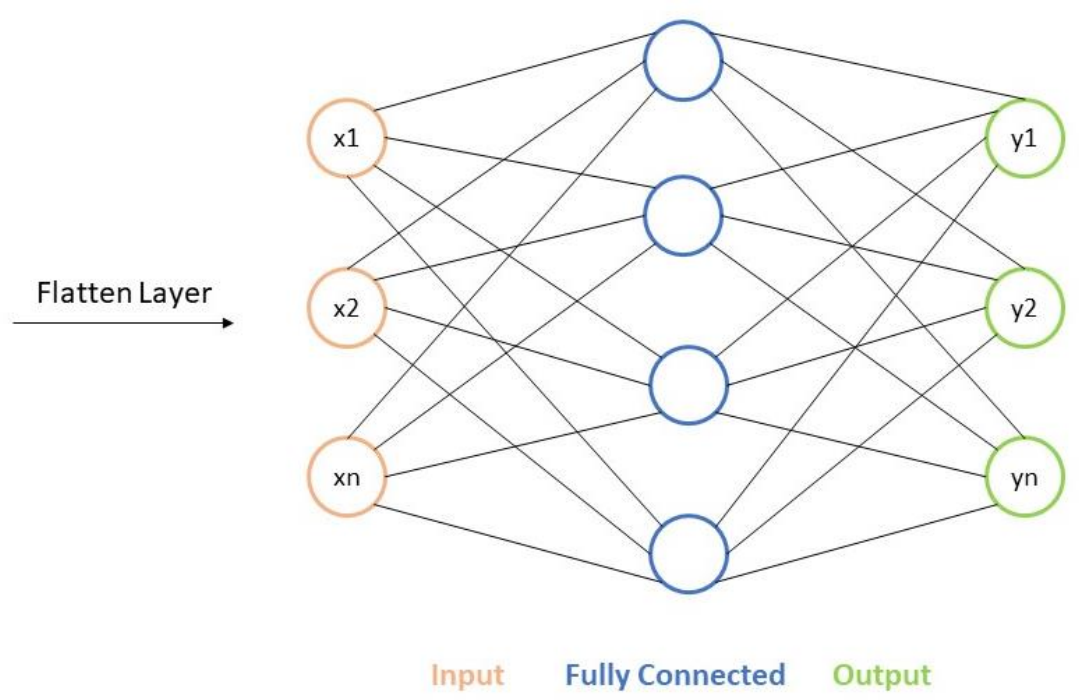

Gambar 6. Fully Connected Layer [15]

\subsection{Performance}

Untuk evaluasi dilakukan perhitungan akurasi dengan menggunakan persamaan berikut:

$$
\text { accuracy }=\frac{\text { number of corect detection }}{\text { total amount of data }} * 100
$$

\section{HASIL DAN PEMBAHASAN}

Tahap awal yaitu akuisisi data, pada tahapan akuisisi data didapatkan hasil berupa citra ikan sebanyak 40 citra dengan kondisi segar sebanyak 20 citra dan juga 20 citra dengan kondisi tidak segar. Setelah itu didapatkan data training sebanyak 24 citra yang terdiri dari 12 citra ikan pada kondisi segar dan 12 gambar pada kondisi tidak segar. Sedangkan untuk data validation dan data testing yang digunakan masing-masing terdiri dari 8 citra yang terdiri dari 4 citra ikan pada kondisi segar dan 4 citra ikan pada kondisi tidak segar. Beberapa sampel hasil akuisisi data yang akan diajdikan bahan penelitian ditunjukan pada Gambar 7 dan Gambar 8. 

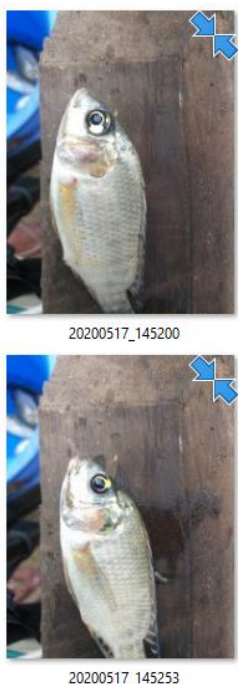

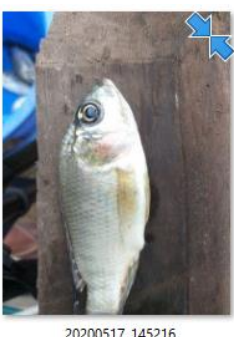

20200517.145216

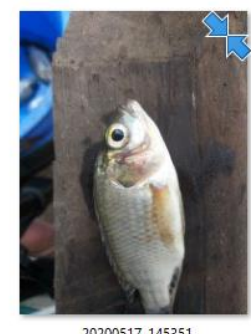

20200517.145351

Gambar 7. Data Citra Ikan Segar

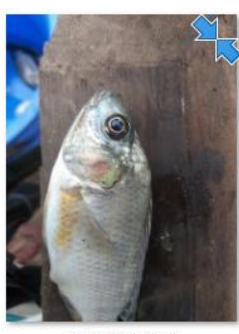

20200517_145427

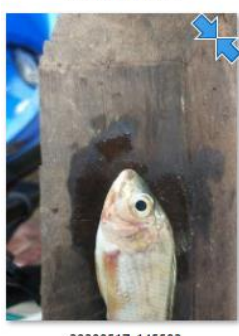

20200517_145502

Setelah didapatkan data citra ikan dengan dimensi 4608×3546 piksel kemudian dilakukan preprocessing citra dengan cara cropping. Citra dipotong dan diseragamkan menjadi citra dengan dimensi 500x500 piksel, sehingga akan mempercepat proses komputasi. Beberapa sampel hasil proses cropping yang akan diadikan bahan penelitian ditunjukkan pada Gambar 9 dan Gambar 10.

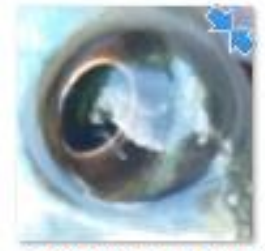

20200517_084015

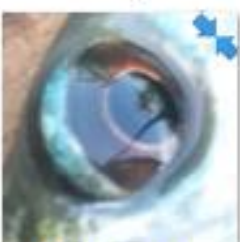

20200517084411

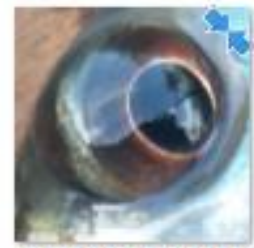

20200517_084054

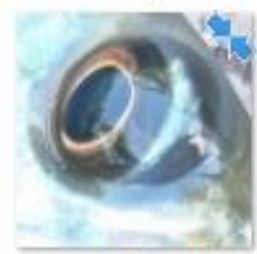

20200517084438

Gambar 9. Data Citra Cropping Ikan Segar

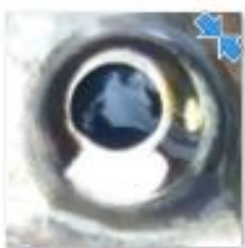

20200517_145200

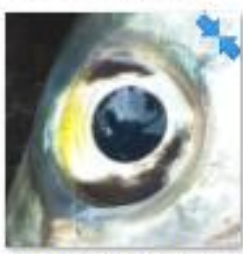

20200517_145520

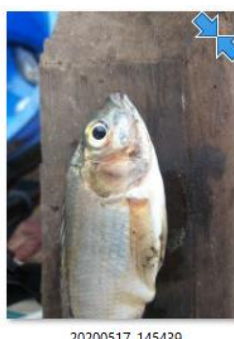

20200517_145439

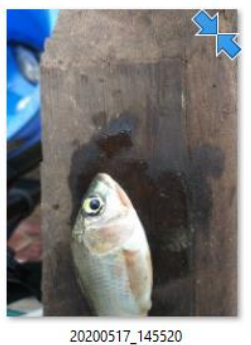

Tidak Segar 


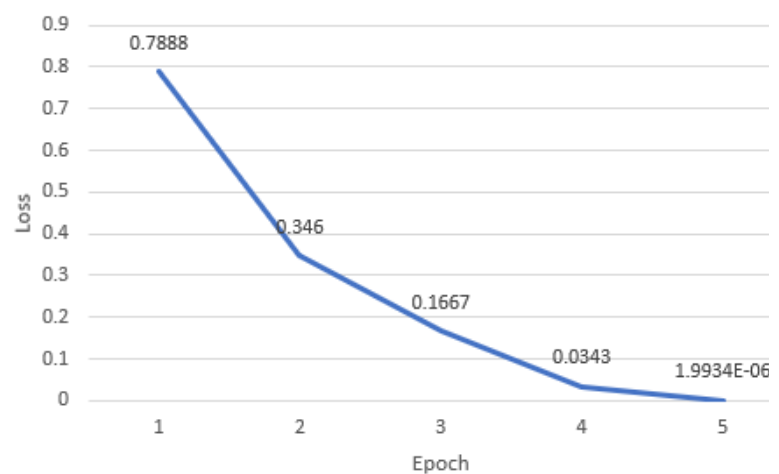

Gambar 11. Train Loss Value

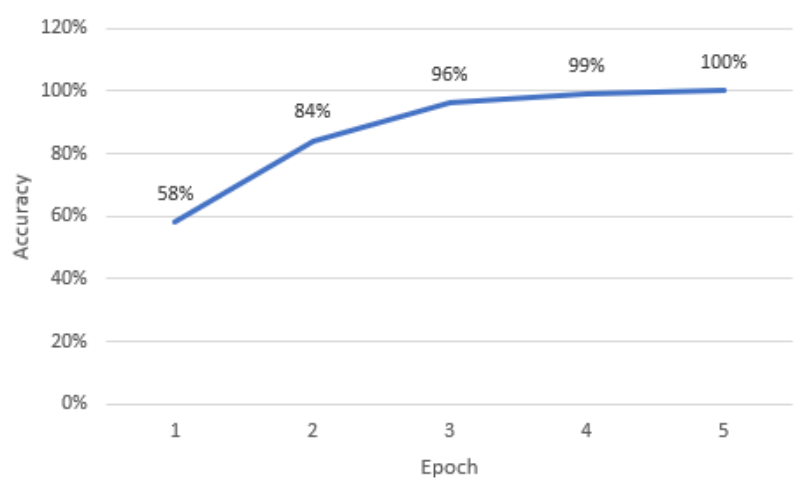

Gambar 12. Train Accuracy

Setelah prose training menggunakan data training, kemudian dilakukan validation menggunakan data validation yang telah disiapkan. Validasi model dilakukan untuk mencegah overfitting. Pada epoch pertama didapatkan loss value sebesar 1.099 sedangkan untuk akurasi sebesar $55 \%$. Sedangkan pada epoch 5 loss value sebesar 0.00020277 dengan akurasi mencapai 100\%. Detail loss value dan akurasi tiap epoch ditunjukan pada Gambar 13 dan Gambar 14.

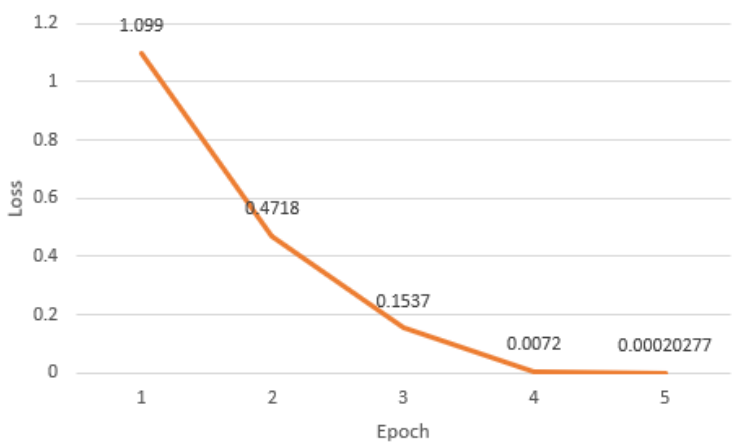

Gambar 13. Validation Loss Value

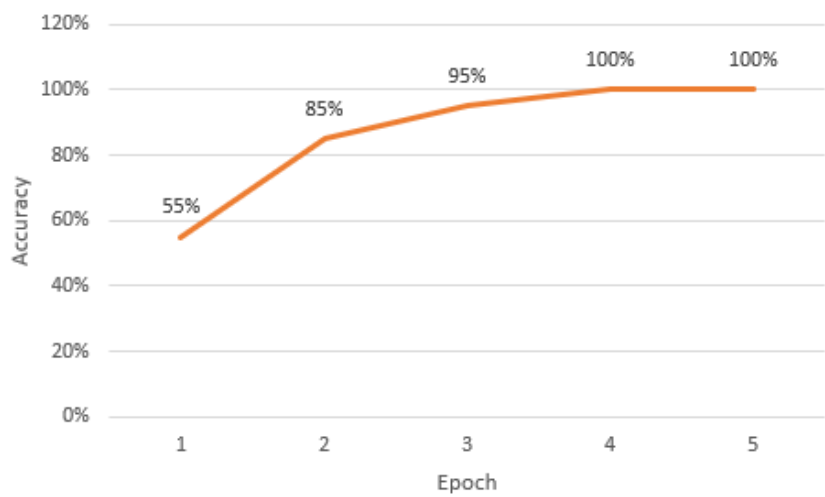

Gambar 14. Validation Accuracy

Setelah dilakukan training dan validation bisa dilihat bahwa model CNN yang dibuat sangat bagus. Kemudian dilakukan testing dengan menggunakan 8 citra yang terdiri dari 4 citra ikan segar dan 4 citra ikan tidak segar. Rincian hasil testing yang dilakukan dapat dilihat pada Tabel 1.

Tabel 1. Hasil pengujian model

\begin{tabular}{cccc}
\hline No. & Citra Uji & Kondisi & Hasil Uji \\
\hline 1 & & Segar & Segar \\
& & & \\
\hline 2 & & & \\
& & & \\
& & & \\
& & & \\
& & &
\end{tabular}




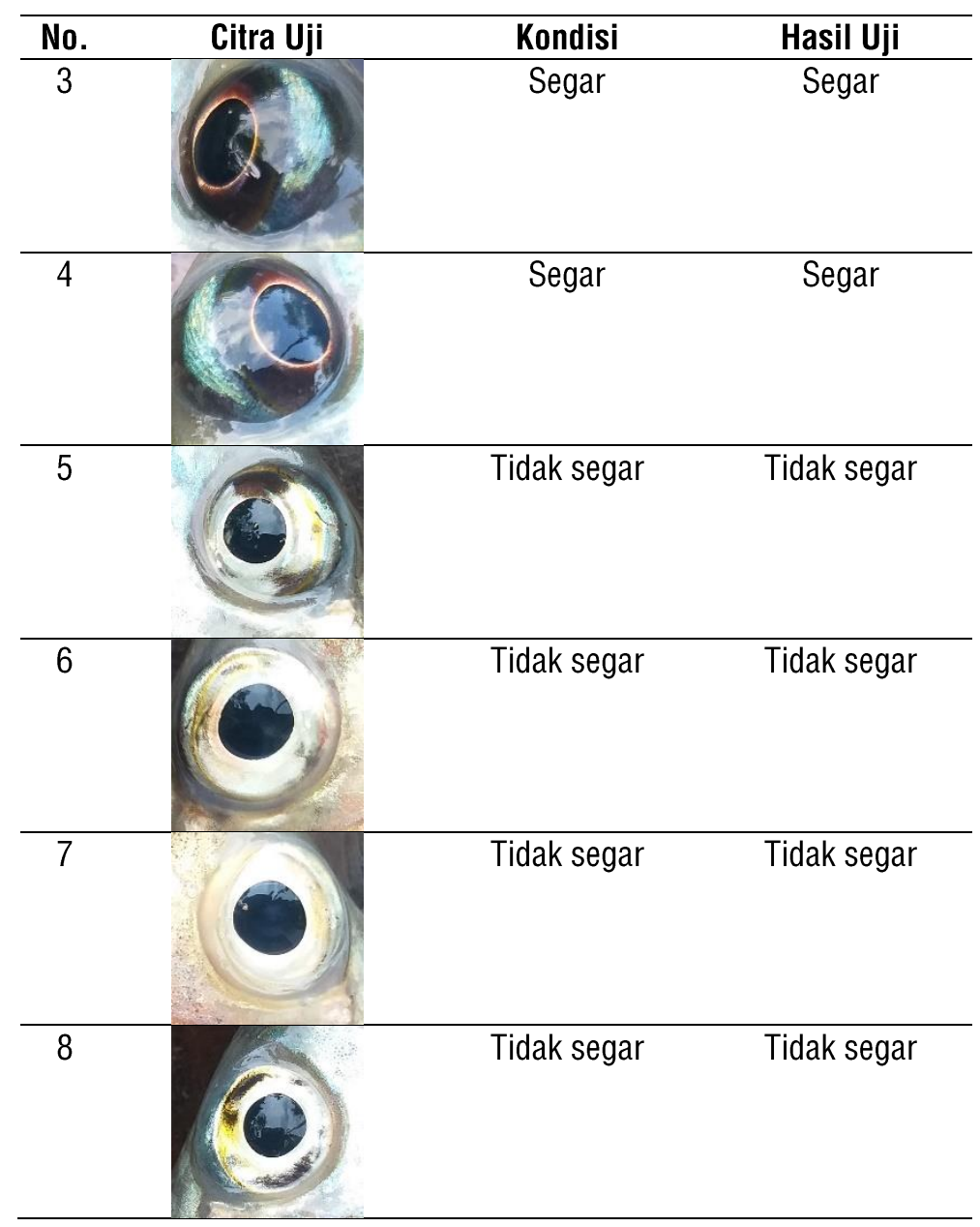

Berdasarkan Tabel 1, diketahui bahwa pada data uji yang berjumlah 8 citra model klasifikasi yang telah dibuat mampu mengenali data citra ikan yang segar dan ikan yang tidak segar dengan tingkat akurasi yang sangat baik yaitu $100 \%$.

\section{KESIMPULAN}

Dari hasil penelitian dan pembahasan pengolahan citra menggunaka Concolutional Neural Network (CNN) dalam mengklasifikasikan citra ikan dapat ditarik kesimpulan bahwa tingkat akurasi yang diperoleh dari model Convolutional Neural Network (CNN) yaitu sebesar $100 \%$ baik pada proses training, validation, dan juga testing. Sehingga dapat disimpulkan bahwa penerapan Deep Learning dengan menggunakan metode Convolutional Neural Network(CNN) mampu mengklasifikasikan citra ikan segar dan tidak segar dengan sangat baik. Hasil klasifikasi pada data testing sebanyak 8 citra ikan untuk menguji model menunjukan semua citra berhasil diklasifikasi dengan benar.

\section{UCAPAN TERIMA KASIH}

Ucapan terima kasih peneliti sampaikan kepada dosen pengampu mata kuliah Pengenalan Pola yang telah membimbing dalam melakukan penelitian. Kepada orang tua dan keluarga tercinta yang telah membantu dalam bentuk material dan non material. Serta teman-teman yang telah mendukung dan membantu selama penelitian.

\section{DAFTAR PUSTAKA}

[1] M. D. Ramadhan and B. Setiyono, "Pengolahan Citra untuk Mengetahui Tingkat Kesegaran Ikan Menggunakan Metode Transformasi Wavelet Diskrit," J. Sains dan Seni ITS, vol. 8, no. 1, pp. 23-28, 2019.

[2] S. Dwiyanto, Iksal, and S. Nugraha, "Alat Pendeteksi Kesegaran Ikan Menggunakan Metode K-Nearest Neighbor Berdasar Warna Mata Berbasis ATMega 328," J. PROSISKO, vol. 5, no. 2, pp. 127-135, 2018. 
[3] H. F. Astuti, Pengolahan Citra Digital Konsep dan Teori. Yogyakarta: Andi, 2013.

[4] L. Marifatul Azizah, S. Fadillah Umayah, and F. Fajar, "Deteksi Kecacatan Permukaan Buah Manggis Menggunakan Metode Deep Learning dengan Konvolusi Multilayer," Semesta Tek., vol. 21, no. 2, pp. 230236, 2018.

[5] R. Feng, J. Gu, Y. Qiao, and C. Dong, "Suppressing Model Overfitting for Image Super-Resolution Networks," in IEEE Computer Society Conference on Computer Vision and Pattern Recognition Workshops, 2019, vol. 2019-June, pp. 1964-1973.

[6] V. Maha, P. Salawazo, D. Putra, J. Gea, F. Teknologi, and U. P. Indonesia, "Implementasi Metode Convolutional Neural Network ( CNN ) Pada Peneganalan Objek Video Cctv," J. Mantik Penusa, vol. 3, no. 1, pp. 74-79, 2019.

[7] I. W. S. E. Putra, "Klasifikasi Citra Menggunakan Convolutional Neural Network ( Cnn ) Pada Caltech 101," Institut Teknologi Sepuluh Nopember, 2016.

[8] E. N. Arrofiqoh and H. Harintaka, "Implementasi Metode Convolutional Neural Network Untuk Klasifikasi Tanaman Pada Citra Resolusi Tinggi," Geomatika, vol. 24, no. 2, p. 61, 2018.

[9] A. Thohari and G. B. Hertantyo, "Implementasi Convolutional Neural Network untuk Klasifikasi Pembalap MotoGP Berbasis GPU," in Proceedings on Conference on Electrical Engineering, Telematics, Industrial Technology, and Creative Media, 2018, pp. 50-55.

[10] N. M. S. Iswari, W. Wella, and R. Ranny, "Perbandingan Algoritma kNN, C4.5, dan Naive Bayes dalam Pengklasifikasian Kesegaran Ikan Menggunakan Media Foto," J. Ultim., vol. 9, no. 2, pp. 114-117, 2017.

[11] L. Cahyono and S. Supatman, "Identifikasi Daging Sapi Segar Dan Beku Menggunakan Learning Vector Quantization," JMAI (Jurnal Multimed. Artif. Intell., vol. 2, no. 2, pp. 37-44, 2018.

[12] Q. Lina, "Apa itu Convolutional Neural Network?," 2019. [Online]. Available: https://mc.ai/apa-ituconvolutional-neural-network/.

[13] Sukardi, Z. Arifin, and M. Risaldi, "Klasifikasi Penentuan Gambar Berbasis Tensorform Dan Framework Dengan Algoritma CNN," in Seminar Nasional APTIKOM (SEMNASTIKOM), 2017, no. November, pp. 1-4.

[14] R. Kestrilia, C. Ivan, and H. Setiawan, "Implementasi Convolutional Neural Network untuk Sistem Prediksi Pigmen Fotosintesis pada Tanaman Secara Real Time," J. Tek. Inform. dan Sist. Inf., vol. 4, no. 2, pp. 326336, 2018.

[15] S. Fauzi, P. Eosina, and G. F. Laxmi, "Implementasi Convolutional Neural Network Untuk Identifikasi Ikan Air Tawar," in Seminar Nasional Teknologi Informasi, 2019. 